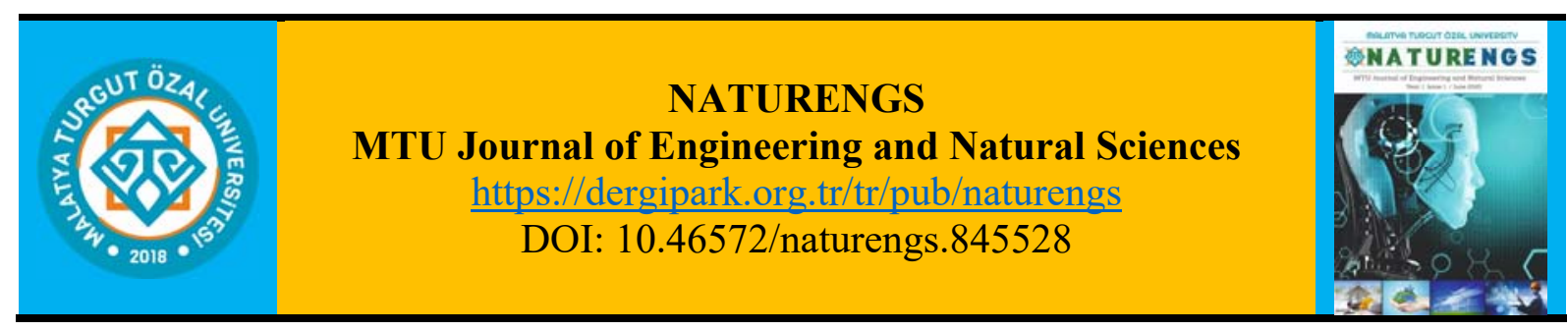

Research Article

\title{
Investigation of Hygiene Knowledge Levels of Kitchen Staff in Diyarbakir Provincial State Hospitals
}

\author{
Gurbet EREN $^{1 *}$, Aylin SEYLAM KÜŞÜMLER ${ }^{2}$ \\ 1,2 Department of Nutrition and Dietetics, İstanbul Okan University, İstanbul, Turkey.
}

(Received: 24.01.2021; Accepted: 10.07.2021)

\begin{abstract}
This research was carried out to investigate the hygiene knowledge level of the personnel working in the nutrition/beverage service and kitchen of hospitals that provide mass feeding in Diyarbakır. For this purpose, a survey form of 94 questions was applied to a total of 150 people, 117 men and 33 women, working in three hospital kitchens in the central district of Diyarbakır. The study was initiated after the approval of the ethics committee of Okan University, dated 08.05.2019 with meeting number 108 and decision number 6 . According to the data obtained from the research, $78 \%$ of the staff working in the institutional kitchens in Diyarbakir province were male and $22 \%$ were female. It was determined that the job duration in the profession was concentrated between $2-5$ years $(40.7 \%)$. Also, it is seen that the person who received hygiene training makes up the vast majority, such as $95.3 \%$.

A significant difference was found between the groups in terms of personal hygiene and personnel hygiene competence and also between the age groups of the personnel who participated in our study. It has been observed that the knowledge of all those who got HACCP training at school is sufficient while others (who got training in a course or masters) have less knowledge. It has been observed that the knowledge of the staff on hand hygiene and HACCP system is low. Moreover, it has been observed that the personnel knowledge on hand hygiene and HACCP system is low.
\end{abstract}

Keywords: Hygiene, Food hygiene, Institutional kitchen, Mass feeding.

\section{INTRODUCTION}

Mass feeding is the feeding of people outside the home with nutrients and meals offered through institutions. Places that provide mass feeding are institutions that manage and program nutrition programs of a certain segment from a center. Research has shown that approximately 1/10 of Turkey's population is fed by mass feeding services $[1,2]$.

Mass Feeding Systems (MFS) have developed in parallel with the development of technology since the middle ages [3]. Universities, schools, hospitals, workplaces, nursing homes for the elderly and needy, military, kindergartens, prisons, and correctional houses can be included for mass feeding institutions. Hotels, self-service restaurants, restaurants, fast-food restaurants, public transport enterprises, recreation and entertainment places are included in the group of commercial enterprises [4]. Due to its wide scope and complex structure, Mass Feeding Systems (MFS) services can have dangerous consequences for public health if hygiene/sanitation is not attached importance [5]. The issue is important in terms of nutrition, 
health, and the expectations of those who benefit from the service. Failure, carelessness that may occur at any step of the service can lead to food poisoning which can result in death [6]. The staff must be healthy when dealing with food to ensure hygienic cleaning of clothes, hands and bodies. Some unconscious practices while preparing meals can lead to mass food poisoning. Therefore, personnel interested in food processing should be given training that includes the main principles of healthy food preparation and personal hygiene matters. In particular, time and temperature control, personnel hygiene, sources of cross-contamination and factors affecting the proliferation of pathogens in food should be taught and this training should be given periodically [7]. Diseases that can be transmitted by food products, new production methods, genetically modified organisms (GMO), pesticides, and similar issues that constitute health risks have revealed the need to determine the main elements in food hygiene and safety. That's why, Law No. 5996 on Veterinary Services, Plant Health, Food and Feed and the provisions on food hygiene and safety in our country have been adapted to the European Union norms and minimum standards to be complied with have been regulated [8, 9]. In addition, provisions regarding the training to be received by personnel working on food hygiene are regulated by law and a Hygiene Training Regulation on the implementation of the provisions has been published. In the regulation, the procedures and principles regarding the planning of hygiene training for employees, delivering training, determining infectious diseases and skin diseases that prevent employees working in these workplaces, the treatment of these diseases and the responsibilities of the workplace owners, operators and employees are identified [10, 11]. In a study conducted on sanitation and hygiene training for protecting and improving health, the necessity to train those who deal with food for the control and prevention of foodborne diseases was reported $[12,13]$.

People are affected by many stimulants around them from birth to death. Due to the constant change of conditions, education has a great share in adapting to the new conditions. That's why education needs to be continuous [14]. Considering that education is a dynamic process, the continuity of the training to be given to the person should also be taken into account in institutions where mass feeding is provided [15].

Although most of the employees in the food production and distribution sector are given hygiene training, it is seen that the knowledge of the people about food and personal hygiene is often not sufficient. For this reason, there is a need for studies to measure the level of knowledge about the hygiene knowledge level of the personnel working in mass feeding establishments. This study, it was aimed to investigate the level of knowledge of food hygiene and personal hygiene of the employees in the kitchens of the institutions in Diyarbakır.

\section{MATERIAL AND METHODS}

This study aims to evaluate the up-to-date knowledge level of 117 male and 33 female personnel working in hospital kitchens in Diyarbakır city center, which constitutes the population of the study, on food hygiene and safety, personal and personnel hygiene, equipment hygiene, and HACCP to determine the knowledge level of the personnel on food and personnel hygiene.

This study is descriptive and cross-sectional research and was carried out by the staff of food companies that provide food production and distribution services to three state hospitals in the central districts (Yenisehir, Sur) of Diyarbakir. In the selection of the study population, these districts were chosen as research regions because of the large number of institutional kitchens in these regions. It was determined that a total of 400 kitchen personnel were working. Volunteerism was taken as a basis in personnel selection. The participation of $150(\mathrm{M}+\mathrm{F})$ personnel was ensured. The formula given below was used to determine the sample volume. 
N.p.q

$\mathrm{n}=(N-1) .(Z \propto 2 \backslash d) 2+p . q$

$\mathrm{N}$ : Research material (main mass)

$\mathrm{n}$ : Sample volume

$\mathrm{Z} \alpha / 2$ : Confidence coefficient

d: Sampling error

p: Incidence (probability) of the studied event

q: Frequency of the absence of the studied event (probability; 1-p)

When the formula was applied, the sample size was found to be 150 . In the formula applied, $90 \%$ confidence coefficient and $20 \%$ margin of error were taken into account. The general rule applied in this type of sampling was accepted as $(p)=(q)=0.5$. In this case, the largest possible sample volume was obtained with a fixed sampling error [16].

To test our hypotheses and meet the study objectives at the best possible level, the questionnaire was prepared by considering the issues stated by the experts in this field and the previous empirical studies.

The questions in the questionnaire form were created based on food hygiene, personnel hygiene and equipment hygiene $[17,18]$. When the formula was applied, the sample size was found to be 150 . In the formula applied, $90 \%$ confidence coefficient and $20 \%$ margin of error were taken into account. The general rule applied in this type of sampling was accepted as $(p)=(q)=0.5$. In this case, the largest possible sample volume was obtained with a fixed sampling error [16].

To test the developed hypotheses and to realize the research objectives at the best possible level, the questionnaire questions were prepared by considering the issues stated by the experts in this field and the previous empirical studies. The questions in the questionnaire form were created by making use of food hygiene, personnel hygiene and equipment hygiene [17, 18]. A questionnaire consisting of 94 questions in which information about economic and social (demographic) characteristics, hygiene education, food hygiene and food safety, personal and personnel hygiene, equipment hygiene, and HACCP system were asked to be evaluated was applied. In the analysis, the correct answer was evaluated as 1 (one), the wrong answer as -1 (minus one) and "I don't know" as 0 (zero) points, and the triple Likert scale was used. The knowledge points of the participants in the study were obtained. By taking the average of their knowledge scores, those who are at or below the average score are deemed to have insufficient knowledge, and those with above-average scores are deemed to have sufficient knowledge. The results were evaluated in 2 groups as sufficient and insufficient knowledge levels [19]. The collected data were analyzed using the Statistical Package for Social Sciences (SPSS), version 24.0. In its statistical evaluation; percentage (\%), frequency distribution (f), arithmetic mean, standard deviation, Pearson Chi-Square, Fisher's exact test and Chi-square statistical analysis were used to compare knowledge competencies with other variables. Results were evaluated at a $95 \%$ confidence interval and $\mathrm{p}<0.05$ significance level. 


\section{RESULTS AND DISCUSSION}

$78.0 \%$ of the participants are men and $22.0 \%$ are women. It was observed that $44.0 \%$ of the participants were between the ages of 31-40. Looking at the marital status of the participants, it is seen that the majority $(75.3 \%)$ are married. Considering the distribution by educational status, it was seen that $12.0 \%$ of them were higher education graduates. Considering the distribution according to their titles, the largest group in the institutional kitchens is the other group with 47 . $3 \%$, while $12.7 \%$ are the chefs, $16.0 \%$ are the section chiefs and $4.7 \%$ are the master chefs. Considering the distribution by professional seniority, $58.0 \%$ of them are between 1-5 years. Those with professional seniority over 10 years are $15.3 \%$ and those between 6-10 years are $26.7 \%$. Considering the distribution of the participants according to their smoking status, it is seen that more than half $(65.4 \%)$ of the kitchen workers of the institution do not smoke. The distribution of the average scores of the participants from the questionnaires and the hygiene knowledge sufficiency ratios according to the surveys are given in Table 1.

Table 1. Evaluating the scores of the participants from surveys

\begin{tabular}{cccc}
\hline & & $\mathbf{n}$ & $\mathbf{\%}$ \\
\hline $\begin{array}{c}\text { Food hygiene and safety } \\
\text { qualification }\end{array}$ & Sufficient & 86 & 57.3 \\
\cline { 2 - 4 } $\begin{array}{c}\text { Personal hygiene and staff hygiene } \\
\text { qualification }\end{array}$ & Sufficient & 64 & 42.7 \\
\cline { 2 - 4 } $\begin{array}{c}\text { Insufficient } \\
\text { Equipment hygiene qualification }\end{array}$ & Sufficient & 70 & 46.7 \\
\cline { 2 - 4 } & Insufficient & 80 & 53.3 \\
\hline HACCP system knowledge & Sufficient & 65 & 56.7 \\
\cline { 2 - 4 } sufficiency & Insufficient & 69 & 43.3 \\
\hline
\end{tabular}

When looking at the calculation made using the triple Likert scale of the participants, the hygiene score average is 32.6 . Those below this average were considered insufficient, and those above this average were considered sufficient. During the evaluation, the total score they should get was evaluated as $100 \%$, and other averages and percentage calculations were made. It was determined that food hygiene and safety knowledge of $56.4 \%$ of the personnel, personal hygiene and personnel hygiene knowledge of $38 \%$ of the personnel, equipment and tools hygiene knowledge of $41.8 \%$ of the personnel, and HACCP knowledge of $71 \%$ of the personnel were above the average level. When Table 1 is examined, food hygiene and safety sufficiency, personal hygiene and personnel hygiene sufficiency, equipment hygiene sufficiency scored above average. The distribution of food hygiene and safety sufficiency ratios according to the demographic characteristics of the participants is given in Table 2 in numbers and percentage values. 
Table 2. Food hygiene and food safety sufficiency ratios according to the demographic characteristics of the participants

\begin{tabular}{|c|c|c|c|c|c|c|c|}
\hline \multirow{3}{*}{ Demographic featur } & & \multicolumn{4}{|c|}{ Food Hygiene and Food Safety } & \multirow{3}{*}{$\mathbf{X}^{2}$} & \multirow{3}{*}{$\mathbf{P}$} \\
\hline & & \multicolumn{2}{|c|}{ Sufficient } & \multicolumn{2}{|c|}{ Insufficient } & & \\
\hline & & $\mathbf{N}$ & $\%$ & $\mathbf{n}$ & $\%$ & & \\
\hline \multirow{2}{*}{ Gender } & Male & 68 & 58.1 & 49 & 41.9 & \multirow{2}{*}{0.134} & \multirow{2}{*}{0.714} \\
\hline & Female & 18 & 54.5 & 15 & 45.5 & & \\
\hline \multirow{3}{*}{ Age } & Age 30 and under & 20 & 54.1 & 17 & 45.9 & \multirow{3}{*}{1.183} & \multirow{3}{*}{0.553} \\
\hline & $31-40$ age & 36 & 54.5 & 30 & 45.5 & & \\
\hline & Over 40 years old & 30 & 63.8 & 17 & 36.2 & & \\
\hline \multirow{5}{*}{ Educational status } & Literate & 17 & 54.8 & 14 & 45.2 & \multirow{5}{*}{4.809} & \multirow{5}{*}{0.307} \\
\hline & primary school & 17 & 56.7 & 13 & 43.3 & & \\
\hline & middle School & 19 & 46.3 & 22 & 53.7 & & \\
\hline & High school & 20 & 66.7 & 10 & 33.3 & & \\
\hline & Higher education & 13 & 72.2 & 5 & 27.8 & & \\
\hline \multirow{2}{*}{$\begin{array}{c}\text { Type of } \\
\text { employment }\end{array}$} & Full-time & 80 & 58 & 58 & 42 & \multirow{2}{*}{0.287} & \multirow{2}{*}{0.592} \\
\hline & Part-time & 6 & 50 & 6 & 50 & & \\
\hline \multirow{6}{*}{ Title } & Intern & 2 & 100 & - & - & \multirow{6}{*}{6.341} & \multirow{6}{*}{0.256} \\
\hline & Assistant Chef & 14 & 51.9 & 13 & 48.1 & & \\
\hline & Chef & 15 & 78.9 & 4 & 21.1 & & \\
\hline & Section chief & 12 & 50 & 12 & 50 & & \\
\hline & Masterchef & 3 & 42.9 & 4 & 57.1 & & \\
\hline & Other & 40 & 56.3 & 31 & 43.7 & & \\
\hline \multirow{4}{*}{ Experience } & 1 year & 15 & 57.7 & 11 & 42.3 & \multirow{4}{*}{1.854} & \multirow{4}{*}{0.603} \\
\hline & $2-5$ year & 34 & 55.7 & 27 & 44.3 & & \\
\hline & $6-10$ year & 21 & 52.5 & 19 & 47.5 & & \\
\hline & More than 10 years & 16 & 69.6 & 7 & 30.4 & & \\
\hline \multirow{4}{*}{$\begin{array}{c}\text { Where he/she } \\
\text { learned his/her job }\end{array}$} & At school & 7 & 100 & - & - & \multirow{4}{*}{6.513} & \multirow{4}{*}{0.080} \\
\hline & In a course & 7 & 50 & 7 & 50 & & \\
\hline & On-the-job training & 56 & 57.7 & 41 & 42.3 & & \\
\hline & Other & 16 & 50 & 16 & 50 & & \\
\hline \multirow{2}{*}{$\begin{array}{l}\text { Average working } \\
\text { time per week }\end{array}$} & 40 hours and less & 57 & 60.6 & 37 & 39.4 & 1124 & 0280 \\
\hline & More than 40 hours & 29 & 51.8 & 27 & 48.2 & ד 1.12 & 0.203 \\
\hline Cooking & Yes & 37 & 63.8 & 21 & 36.2 & & \\
\hline $\begin{array}{c}\text { profession } \\
\text { certificate status }\end{array}$ & No & 49 & 53.3 & 43 & 46.7 & 1.613 & 0.204 \\
\hline Average monthly & $\begin{array}{c}\text { Minimum wage and } \\
\text { below }\end{array}$ & 65 & 55.6 & 52 & 44.4 & & \\
\hline income & $\begin{array}{l}\text { More than the } \\
\text { minimum wage }\end{array}$ & 21 & 63.6 & 12 & 36.4 & & \\
\hline
\end{tabular}


In Table 2, when the distribution of food hygiene and safety competence results is examined according to the demographic characteristics of the participants, no statistically significant difference was found between the participants in the questionnaire $(p>0.05)$.

The distribution of personal hygiene and personnel hygiene sufficiency ratios according to the demographic characteristics of the kitchen employees of the participating institution is given in Table 3 in numbers and percentage values.

Table 3: Personal hygiene and staff hygiene sufficiency ratios according to the demographic characteristics of the participants

\begin{tabular}{|c|c|c|c|c|c|c|c|}
\hline \multicolumn{2}{|c|}{ Demographic features } & \multirow{2}{*}{\multicolumn{4}{|c|}{$\begin{array}{c}\text { Personal Hygiene and } \\
\text { Personnel Hygiene }\end{array}$}} & \multirow{4}{*}{$\mathbf{X}^{2}$} & \multirow{4}{*}{$\mathbf{P}$} \\
\hline & & & & & & & \\
\hline & & \multicolumn{2}{|c|}{ Sufficient } & \multicolumn{2}{|c|}{ Insufficient } & & \\
\hline & & $\mathbf{n}$ & $\%$ & $\mathbf{n}$ & $\%$ & & \\
\hline \multirow[t]{2}{*}{ Gender } & Male & 52 & 44.4 & 65 & 55.6 & \multirow{2}{*}{1.055} & \multirow{2}{*}{0.304} \\
\hline & Female & 18 & 54.5 & 15 & 45.5 & & \\
\hline \multirow{3}{*}{ Age } & Age 30 and under & 18 & 48.6 & 19 & 51.4 & \multirow{3}{*}{6.020} & \multirow{3}{*}{$0.049 *$} \\
\hline & 31-40 Age & 24 & 36.4 & 42 & 63.6 & & \\
\hline & Over 40 years old & 28 & 59.6 & 19 & 40.4 & & \\
\hline \multirow{5}{*}{ Educational status } & Literate & 15 & 48.4 & 16 & 51.6 & \multirow{5}{*}{5.610} & \multirow{5}{*}{0.230} \\
\hline & Primary school & 9 & 30.0 & 21 & 70.0 & & \\
\hline & Middle School & 19 & 46.3 & 22 & 53.7 & & \\
\hline & High school & 18 & 60.0 & 12 & 40.0 & & \\
\hline & Higher education & 9 & 50.0 & 9 & 50.0 & & \\
\hline \multirow{2}{*}{$\begin{array}{l}\text { Type of } \\
\text { employment }\end{array}$} & Full-Time & 68 & 49.3 & 70 & 50.7 & \multirow{2}{*}{4.717} & \multirow{2}{*}{$0.030 *$} \\
\hline & Part- Time & 2 & 16.7 & 10 & 83.3 & & \\
\hline \multirow{6}{*}{ Title } & Intern & 1 & 50.0 & 1 & 50.0 & \multirow{6}{*}{4.111} & \multirow{6}{*}{0.550} \\
\hline & Assistant Chef & 13 & 48.1 & 14 & 51.9 & & \\
\hline & Chef & 5 & 26.3 & 14 & 73.7 & & \\
\hline & Section chief & 12 & 50.0 & 12 & 50.0 & & \\
\hline & Masterchef & 3 & 42.9 & 4 & 57.1 & & \\
\hline & Other & 36 & 50.7 & 35 & 49.3 & & \\
\hline \multirow{4}{*}{ Experience } & 1 year & 13 & 50.0 & 13 & 50.0 & \multirow{4}{*}{1.816} & \multirow{4}{*}{0.611} \\
\hline & $2-5$ year & 25 & 41.0 & 36 & 59.0 & & \\
\hline & $6-10$ year & 19 & 47.5 & 21 & 52.5 & & \\
\hline & More than 10 years & 13 & 56.5 & 10 & 43.5 & & \\
\hline \multirow{5}{*}{$\begin{array}{l}\text { Where he/she } \\
\text { learned his/her job }\end{array}$} & At school & 6 & 85.7 & 1 & 14.3 & \multirow{5}{*}{4.444} & \multirow{5}{*}{0.215} \\
\hline & the course & 6 & 42.9 & 8 & 57.1 & & \\
\hline & at the workplace & 43 & 44.3 & 54 & 55.7 & & \\
\hline & next to the master & & & & & & \\
\hline & Other & 15 & 46.9 & 17 & 53.1 & & \\
\hline
\end{tabular}




\begin{tabular}{|c|c|c|c|c|c|c|c|}
\hline \multirow{2}{*}{$\begin{array}{l}\text { Average working } \\
\text { time per week }\end{array}$} & 40 hours and less & 41 & 43.6 & 53 & 56.4 & \multirow{2}{*}{0.941} & \multirow{2}{*}{0.332} \\
\hline & More than 40 hours & 29 & 51.8 & 27 & 48.2 & & \\
\hline \multirow{2}{*}{$\begin{array}{l}\text { Cooking profession } \\
\text { certificate status }\end{array}$} & Yes & 27 & 46.6 & 31 & 53.4 & \multirow{2}{*}{0.001} & \multirow{2}{*}{0.982} \\
\hline & No & 43 & 46.7 & 49 & 53.3 & & \\
\hline \multirow{2}{*}{$\begin{array}{l}\text { Average monthly } \\
\text { income }\end{array}$} & Minimum wage and below & 54 & 46.2 & 63 & 53.8 & \multirow{2}{*}{0.056} & \multirow{2}{*}{0.813} \\
\hline & $\begin{array}{l}\text { More than the minimum } \\
\text { wage }\end{array}$ & 16 & 48.5 & 17 & 51.5 & & \\
\hline
\end{tabular}

The distribution of personal hygiene and staff hygiene sufficiency ratios according to the demographic characteristics of the participants was examined; a statistically significant difference was found between the groups in terms of age and type of employment $(p<0.05)$.

According to the demographic characteristics of the participants, the distribution of equipment hygiene qualification ratios is given in Table 4 in numbers and percentage values.

Table 4. Equipment hygiene qualification according to the demographic characteristics of the participants

\begin{tabular}{|c|c|c|c|c|c|c|c|}
\hline \multirow[t]{3}{*}{ Demographic features } & & \multicolumn{4}{|c|}{ Equipment Hygiene } & \multirow[b]{3}{*}{$\mathbf{X}^{2}$} & \multirow[b]{3}{*}{$\mathbf{P}$} \\
\hline & & \multicolumn{2}{|c|}{ Sufficient } & \multicolumn{2}{|c|}{ Insufficient } & & \\
\hline & & n & $\%$ & $\mathbf{n}$ & $\%$ & & \\
\hline \multirow{2}{*}{ Gender } & Male & 65 & 55.6 & 52 & 44.4 & \multirow{2}{*}{0.267} & \multirow{2}{*}{0.605} \\
\hline & Female & 20 & 60.6 & 13 & 39.4 & & \\
\hline \multirow{3}{*}{ Age } & Age 30 and under & 20 & 54.1 & 17 & 45.9 & \multirow{3}{*}{0.275} & \multirow{3}{*}{0.872} \\
\hline & $31-40$ years & 37 & 56.1 & 29 & 43.9 & & \\
\hline & Over 40 years old & 28 & 59.6 & 19 & 40.4 & & \\
\hline \multirow{5}{*}{ Educational status } & Literate & 16 & 51.6 & 15 & 48.4 & \multirow{5}{*}{3.866} & \multirow{5}{*}{0.424} \\
\hline & Primary school & 14 & 46.7 & 16 & 53.3 & & \\
\hline & Middle School & 23 & 56.1 & 18 & 43.9 & & \\
\hline & High school & 19 & 63.3 & 11 & 36.7 & & \\
\hline & Higher education & 13 & 72.2 & 5 & 27.8 & & \\
\hline \multirow{2}{*}{ Type of employment } & Full-Time & 78 & 56.5 & 60 & 43.5 & \multirow{2}{*}{0.015} & \multirow{2}{*}{0.903} \\
\hline & Part-Time & 7 & 58.3 & 5 & 41.7 & & \\
\hline \multirow{6}{*}{ Title } & Intern & 1 & 50.0 & 1 & 50.0 & \multirow{6}{*}{4.757} & \multirow{6}{*}{0.446} \\
\hline & Assistant Chef. & 15 & 55.6 & 12 & 44.4 & & \\
\hline & Chef & 7 & 36.8 & 12 & 63.2 & & \\
\hline & Section chief & 13 & 54.2 & 11 & 45.8 & & \\
\hline & masterchef & 4 & 57.1 & 3 & 42.9 & & \\
\hline & Other & 45 & 63.4 & 26 & 36.6 & & \\
\hline \multirow{2}{*}{ Experience } & 1 years & 13 & 50.0 & 13 & 50.0 & \multirow{2}{*}{0.978} & \multirow{2}{*}{0.807} \\
\hline & $2-5$ years & 36 & 59.0 & 25 & 41.0 & & \\
\hline
\end{tabular}




\begin{tabular}{|c|c|c|c|c|c|c|c|}
\hline & $6-10$ years & 24 & 60.0 & 16 & 40.0 & & \\
\hline & More than 10 years & 12 & 52.2 & 11 & 47.8 & & \\
\hline \multirow{4}{*}{$\begin{array}{c}\text { Where he/she learned } \\
\text { his/her job }\end{array}$} & At school & 5 & 71.4 & 2 & 28.6 & \multirow{4}{*}{5.124} & \multirow{4}{*}{0.166} \\
\hline & the course & 11 & 78.6 & 3 & 21.4 & & \\
\hline & $\begin{array}{c}\text { at the workplace next } \\
\text { to the master }\end{array}$ & 49 & 50.5 & 48 & 49.5 & & \\
\hline & Other & 20 & 62.5 & 12 & 37.5 & & \\
\hline \multirow{2}{*}{$\begin{array}{c}\text { Average working time } \\
\text { per week }\end{array}$} & 40 hours and less & 50 & 53.2 & 44 & 46.8 & \multirow{2}{*}{1.238} & \multirow{2}{*}{0.266} \\
\hline & More than 40 hours & 35 & 62.5 & 21 & 37.5 & & \\
\hline \multirow{2}{*}{$\begin{array}{l}\text { Cooking profession } \\
\text { certificate status }\end{array}$} & Yes & 32 & 55.2 & 26 & 44.8 & \multirow{2}{*}{0.086} & \multirow{2}{*}{0.769} \\
\hline & No & 53 & 57.6 & 39 & 42.4 & & \\
\hline $\begin{array}{l}\text { Average monthly } \\
\text { income }\end{array}$ & $\begin{array}{l}\text { Minimum wage and } \\
\text { below }\end{array}$ & 63 & 53.8 & 54 & 46.2 & 1.723 & 0.189 \\
\hline
\end{tabular}

When the data to find the questions sufficient according to the demographic characteristics of the participants according to the sufficiency of equipment hygiene, it was determined that there was no statistically significant difference between the groups $(p>0.05)$.

The distribution of knowledge sufficiency ratios regarding the HACCP system according to the demographic characteristics of the participants is given in Table 5 in numbers and percentage values.

Table 5. Sufficiency of HACCP System knowledge according to the demographic characteristics of the participants

\begin{tabular}{|c|c|c|c|c|c|c|c|}
\hline \multirow[t]{4}{*}{ Demographic fe } & & \multirow{2}{*}{\multicolumn{4}{|c|}{$\begin{array}{c}\text { HACCP System } \\
\text { knowledge sufficiency }\end{array}$}} & \multirow{4}{*}{$\mathbf{X}^{2}$} & \multirow{4}{*}{$\mathbf{P}$} \\
\hline & & & & & & & \\
\hline & & \multicolumn{2}{|c|}{ Sufficient } & \multicolumn{2}{|c|}{ Insufficient } & & \\
\hline & & $\mathbf{n}$ & $\%$ & $\mathbf{n}$ & $\%$ & & \\
\hline \multirow{2}{*}{ Gender } & Male & 57 & 48.3 & 61 & 51.7 & \multirow{2}{*}{0.502} & \multirow{2}{*}{0.479} \\
\hline & Female & 12 & 37.5 & 20 & 62.5 & & \\
\hline \multirow{3}{*}{ Age } & Age 30 and under & 19 & 52.8 & 17 & 47.2 & \multirow{3}{*}{6.364} & \multirow{3}{*}{$0.042 *$} \\
\hline & $31-40$ years & 35 & 47.9 & 38 & 52.1 & & \\
\hline & Over 40 years old & 11 & 26.8 & 30 & 73.2 & & \\
\hline \multirow{5}{*}{$\begin{array}{l}\text { Educational } \\
\text { status }\end{array}$} & Literate & 11 & 37.9 & 18 & 62.1 & \multirow{5}{*}{3.640} & \multirow{5}{*}{0.457} \\
\hline & Primary school & 12 & 40 & 18 & 60 & & \\
\hline & Middle School & 14 & 35.9 & 25 & 64.1 & & \\
\hline & High school & 19 & 52.7 & 17 & 47.3 & & \\
\hline & Higher education & 9 & 56.3 & 7 & 43.8 & & \\
\hline \multirow{2}{*}{$\begin{array}{c}\text { Type of } \\
\text { employment }\end{array}$} & Full-Time & 61 & 44.2 & 78 & 55.8 & \multirow{2}{*}{0.212} & \multirow{2}{*}{0.758} \\
\hline & Part-Time & 4 & 36.4 & 7 & 63.6 & & \\
\hline \multirow[b]{3}{*}{ Title } & İntern & 2 & 100 & - & - & \multirow{3}{*}{3.080} & \multirow{3}{*}{0.730} \\
\hline & Assistant Chef. & 11 & 42.3 & 15 & 57.7 & & \\
\hline & Chef & 7 & 41.2 & 10 & 58.8 & & \\
\hline
\end{tabular}




\begin{tabular}{|c|c|c|c|c|c|c|c|}
\hline & Section chief & 8 & 34.8 & 15 & 65.2 & & \\
\hline & masterchef & 3 & 42.9 & 4 & 57.1 & & \\
\hline & Other & 32 & 45.0 & 39 & 55.0 & & \\
\hline \multirow{4}{*}{ Experience } & 1 years & 13 & 52 & 12 & 48 & \multirow{4}{*}{5.760} & \multirow{4}{*}{0.135} \\
\hline & $2-5$ years & 29 & 47.5 & 32 & 52.5 & & \\
\hline & $6-10$ years & 19 & 43.1 & 25 & 56.9 & & \\
\hline & More than 10 years & 4 & 20 & 16 & 80 & & \\
\hline \multirow{4}{*}{$\begin{array}{l}\text { Where he/she } \\
\text { learned his/her } \\
\text { job }\end{array}$} & At school & 6 & 100 & - & - & \multirow{4}{*}{12.891} & \multirow{4}{*}{$0.004 *$} \\
\hline & the course & 10 & 45.4 & 12 & 54.6 & & \\
\hline & $\begin{array}{l}\text { at the workplace next to the } \\
\text { master }\end{array}$ & 31 & 34.4 & 59 & 65.6 & & \\
\hline & Other & 18 & 56.3 & 14 & 43.8 & & \\
\hline \multirow{2}{*}{$\begin{array}{c}\text { Average } \\
\text { working time } \\
\text { per week }\end{array}$} & 40 hours and less & 51 & 51.5 & 48 & 48.5 & \multirow{2}{*}{7.809} & \multirow{2}{*}{$0.005 *$} \\
\hline & More than 40 hours & 14 & 27.5 & 37 & 72.5 & & \\
\hline \multirow{2}{*}{$\begin{array}{c}\text { Cooking } \\
\text { profession } \\
\text { certificate status }\end{array}$} & Yes & 28 & 48.2 & 30 & 51.8 & \multirow[b]{2}{*}{0.958} & \multirow[b]{2}{*}{0.328} \\
\hline & No & 37 & 40.2 & 55 & 59.8 & & \\
\hline \multirow{2}{*}{$\begin{array}{c}\text { Average } \\
\text { monthly income }\end{array}$} & Minimum wage and below & 51 & 43.5 & 66 & 56.5 & \multirow{2}{*}{0.037} & \multirow{2}{*}{0.847} \\
\hline & More than minimum wage & 14 & 42.4 & 19 & 57.6 & & \\
\hline
\end{tabular}

When the distribution of HACCP System knowledge sufficiency ratios according to the demographic characteristics of the personnel is examined, a statistically significant difference was found between the groups in terms of age, where he learned his job and the average working time per week $(\mathrm{p}<0.05)$.

The ratio of women included in our study was found to be $22 \%$. When examining the data, the findings were consistent with the findings of the studies of Berber (2008) and Eser (2017) who stated that Eastern and Southeastern regions of Turkey had the lowest woman employment rates $[20,21]$. The low rate of woman employees compared to man employees can be explained by the fact that the women in these two regions are profoundly affected by the sociological and cultural factors of the society in which they live.

When the age distribution of the personnel working in the kitchens of the institutions was examined, it was found that $44 \%$ of the personnel were between the ages of $31-40,24.7 \%$ were under 30 years old, and $31.3 \%$ were over 40 years old. It is thought that the accumulation of the largest age group between 31 and 40 is due to the demand for more experienced chefs and master chefs for quality products in the food industry.

When the survey data are analyzed according to the education level of the personnel, it was determined that $20.7 \%$ were literate, $20 \%$ were primary school, $27.3 \%$ were secondary school, $20 \%$ were high school graduates, and $12 \%$ were higher education graduates. Çakıroğlu et al. (2008) [22] found that $27.8 \%$ of the employed personnel were primary school graduates, $67.4 \%$ were secondary and high school graduates, and $4.8 \%$ were university graduates. The findings of this study about mass feeding personnel were similar to Çakıroğlu's findings.

When the professional seniority and hygiene knowledge level of the employees who participated in the survey were examined, the total hygiene, food and personal scores of employees with more than 10 years of work experience were found to be higher than those who 
had less than 1 year of work experience. However, it was stated that the difference between them was not statistically significant ( $\mathrm{p}>0.05)$. When the job duration and food, personal, culinary and total hygiene knowledge scores of the individuals were examined, it was found that there was no statistically significant difference between the groups $(p>0.05)$. Although the difference between the employees participating in the survey is not found to be statistically significant, it has been stated that the knowledge of food safety and hygiene rules changes depending on the occupational seniority and working time of the personnel. In a study conducted by Biyıklı (2011) [23], no statistically significant difference was found among the results of the data obtained from the food hygiene, personnel hygiene, kitchen hygiene, equipment hygiene, and total scores according to the professional experiences of the cooks participating in the study. ( $>>0.05$ ). In a study by Ulusoy et al. (2018) [24], the scores of employees with 3-6 years of work experience were found to be lower than those of employees with 2 years or less work experience $(\mathrm{p}<0.05)$.

In hygiene, which is one of the vital issues in mass feeding systems, two issues come to the fore especially. The first of these is the health of the personnel working in food production and the cleanliness of the place where the food is made. The second is that the food is healthy and of good quality and preserved under appropriate conditions. Employees should have an understanding and awareness of personal cleanliness and hygiene and should be trained regularly. The continuity of this training should be monitored because continuous and effective training will help to eliminate the deficiencies $[25,26]$.

When the data about whether the personnel participating in the survey received hygiene training were analyzed, it was seen that $95.3 \%$ got training and $4.7 \%$ did not. It is important to receive training on the subject for employees in places where mass feeding is provided. In the study conducted by Clayton et al. (2002) [15] in England, they reported that even if the people received hygiene training, most of them did not practice hygiene rules. In a study conducted by Eksen et al. (2004) [27] in Muğla, it was reported that 75.6\% of employees working in food production establishments did not receive hygiene training. In another study, it was found that $48 \%$ of some delicatessen and butchers in Istanbul did not receive hygiene training [28]. In addition, as a result of a study conducted by Babür (2007) [29] in Muğla, it was pointed out that there is a parallelism between the high ratio of personnel receiving hygiene training and the detection of good sanitation status. In a study conducted by Erçişli (2005) [30] to find out the knowledge of the personnel working in the institutions that produce and offer mass feeding in Konya, $44 \%$ of the personnel could not even define the concept of hygiene and this was associated with the insufficiency of the in-service training of these institutions.

It is important whether the personnel working in places where mass feeding is provided receive training or not. The ratios obtained in this study are similar to the ratios determined for staff working in hotel kitchens in studies conducted by Siau et al. (2015) and Abdul-Mutalip et al. (2012) in Malaysia [31,32]. In these studies, it was seen that most of the personnel received hygiene training. The reason why the training ratio (58.4\%) obtained by Demirel in mass feeding establishments in Istanbul is higher than the rate obtained by Siau et al. in Malaysia $(27.8 \%)$ and the rate obtained in the study conducted by Baş et al. can be explained by the fact that the requirement of the personnel working in food establishments to receive hygiene training was made mandatory after the studies conducted by Baş et al. and Demirel [33, 34]. However, although it has become obligatory to receive hygiene training in institutions in Turkey from 2013 onwards [35], it was determined that among the personnel working in the institutions surveyed in this study, few people have not received this training yet (Table 2). 


\section{CONCLUSIONS}

$44 \%$ of the personnel participating in the survey are between the ages of $31-40.78 .0 \%$ of the personnel surveyed are men and $22.0 \%$ are women. It is seen that the majority of the employees (75.3\%) participating in the survey are married. $20.7 \%$ of the personnel participating in the survey are literate, $20.0 \%$ are primary school graduates and $27.3 \%$ are secondary school graduates. These are followed by high school graduates with $20.0 \%$ and higher education graduates with $12.0 \%$. The families of slightly more than half $(54.7 \%)$ of the personnel consist of 4-6 people, while $27.3 \%$ of the personnel consist of $1-3$, and $18.0 \%$ of the personnel consist of 6 and more people. While $65.3 \%$ of the employees participating in the survey have a nuclear family structure, it was determined that $27.3 \%$ have extended families and $7.3 \%$ have broken families. While the other staff (houseman, dishwasher, waiter, and cleaner) comprised $47.3 \%$ of the personnel participating in the survey, $12.7 \%$ were chefs, $18.0 \%$ were assistants, $16.0 \%$ were section chiefs and $4.7 \%$ of them were master chefs and $1.3 \%$ were interns. $40.7 \%$ of the personnel's professional seniority in the kitchen was between 2-5 years. Those with a seniority of 10 years or more in the kitchen were $15.3 \%$, those between $6-10$ years were $26.7 \%$ and those for 1 year were $17.3 \%$. It has been observed that the weekly average working hours of $62.7 \%$ of kitchen personnel were 40 hours or less, and $37.3 \%$ of those were more than 40 hours. It is seen that $65.4 \%$ of the personnel do not smoke and $34.6 \%$ of the personnel smoke.

When the distribution of personal hygiene and personnel hygiene sufficiency ratios is examined according to the demographic characteristics of the personnel, a statistically significant difference was found between the age groups $(\mathrm{p}<0.05)$. In the analysis performed, it was determined that the difference in age groups was between cases "over 40" and "31-40 years old". It is seen that those under the age of 40 have a higher percentage of qualification in the HACCP information system than those over the age of 40. It was determined that most of those with insufficient knowledge (73.2\%) were over 40 years old. While it is observed that the HACCP knowledge of those who work more than 40 hours a week is insufficient, it is seen that all of those who received HACCP knowledge at school have sufficient knowledge, others (such as who received it in a course or masters) have less knowledge. The reason for this can be that the hygiene education given at school is more instructive.

The necessary environment and facilities should be provided for the personnel to perform the hygiene training in the simplest manner and by using visual training tools according to their education levels. Dieticians or food engineers trained in this field should be included. When choosing dieticians or food engineers, priority should be given to those with formation training. While the training continue, the person should also be inspected during the production. It is necessary to make the hygiene practices of the personnel a habit, especially the concept of hand hygiene.

It has been observed that the level of knowledge of the personnel on hand hygiene and HACCP system is low. Attention should be paid to these hygiene problems and a realistic approach should be followed in solving these problems. Personnel should also be trained in the subjects they are lacking, and their progress should be checked by re-measuring or observing their hygiene knowledge level.

This section should summarize the main findings and also link to the recommendations. Previous findings in the discussion should not be repeated, the author's results in a broader context of other studies on the subject interpreting them with a minimum of speculation. The conclusion should integrate with the research findings of other studies to provide the readers with a broad base for understanding whether the hypotheses tested were accepted or rejected. 


\section{REFERENCES}

[1] Kutluay, M.T., Birer, S. (1997). Kurum Beslenmesi (5 baskl), Milli Eğitim Basımevi, Ankara.

[2] Sneed, J., Strohbehn, C.H. (2008). Trends Impacting Food Safety in Retail Foodservice: Implications for Dietetics Practice, Journal of the American Dietetic Association, 108: 1170-1177.

[3] Birer, S. (2002). Yemek Hazırlama, Pişirme ve Servisinde Dikkat Edilmesi Gereken Sağlık ve Temizlik Kuralları, Turizmde Sağlık ve Beslenme Sorunları ve Çözümler Sempozyumu, Alanya, 172-183.

[4] Demirci, M. (2005). Beslenme. II. Baskl, Onur Grafik, İstanbul.

[5] Merdol, T.K., Beyhan, Y., Ciğerim, N., Sağlam, F., Tayfur, F., Baş, M., Dağ, A. (2000). Toplu beslenme yapılan kurumlarda çalışan personel için sanitasyon/hijyen eğitimi rehberi, Hatiboğlu Yayınevi, Ankara.

[6] Bulduk, S. (2010). Gıda ve personel hijyeni, Detay Yayınc1lık, Ankara.

[7] Ciğerim, N., Beyhan, Y., Çeliktaş, N. (1995). Ankara'da Yüksek Öğretim Kredi ve Yurtlar Kurumu'na Bağlı Yurt Mutfaklarında Hijyen Durumunun Değerlendirilmesi, Beslenme ve Diyet Dergisi, 24(2): 273-278.

[8] Oğur, S., Aksoy, A., Yılmaz, Z. (2017). Üniversite Öğrencilerinin Genetiği Değiştirilmiş Organizmalar ve Gıdalar Hakkındaki Bilgi Düzeyleri ve Tutumları: Bitlis Eren Üniversitesi Örneği, Food and Health, 3(3): 97-108.

[9] Internet: 5996 Sayılı Veteriner Hizmetleri, Bitki Sağlı̆̆ı, Gıda ve Yem Kanunu. http://www.resmigazete.gov.tr/ Eskiler/2010/06/20100613-12.Htm. (Erişim Tarihi: 15.12.2015).

[10] Aksoy, A., Arıkan, F.B. (2016). Diş Hekimlerinin Bazı Bulaşıcı Hastalıklar (AIDS, Hepatit B, Tüberküloz, Grip, Kabakulak) Konusundaki Farkındalık ve Davranışları. BEÜ Fen Bilimleri Dergisi, 5(2): 113-122.

[11] Internet: Hijyen Eğitimi Yönetmeliği. http://www. Resmigazete. Gov.Tr/ Eskiler/ 2013/07/2013 0705-3. Htm. (Erişim Tarihi: 15.12.2015).

[12] Cevizci, S., Önal, A.E. (2009). Halk sağlığı açısından hijyen ve iyi üretim uygulamaları, Türk Hijyen ve Deneysel Biyoloji Dergisi, 66(2): 73-82.

[13] Angelillo, I.F., Viggiani, N.M., Rizzo, L., Bianco, A. (2000). Food handlers and foodborne diseases: knowledge, attitudes, and reported behavior in Italy, Journal of Food Protection, 63(3): 381-385.

[14] Elmacıŏglu, F., Dündar, C., Topbaş, M., Peşken, Y. (2000). Samsun İl Merkezindeki Hastane Mutfaklarının Hijyen Durumunun Değerlendirilmesi, Türk Hijyen Ve Deneysel Biyoloji Dergisi, 57(2):1-6.

[15] Clayton, D.A., Griffith, C.J., Price, P., Peters, A.C. (2002). Food handlers' beliefs and self-reported practices, International Journal of Environmental Health Research, 25-39.

[16] Köksal, Ş., Soysal, A., Ergör, G., Kaner, G. (2016). İzmir’de Sağlık Kurumlarına Yemek Üretim ve Dağıtım Hizmeti Veren Bir Firmada Çalışanların Gıda Hijyeni İle İlgili Bilgi Ve Davranışları, Türk Hij.Den.Biyol. Derg., 73(2); 139-148.

[17] West, B., Wood, L., Harger, V.F. (1998). Food Service in Institutions, Millan Publishing, New York.

[18] Internet: WHO. Food Safety and Foodborne Illness, Fact sheet No.237, Reviewed March 2007. http://www.who.int/mediacentre/factsheets/fs237/en/print.html, (17.10.2007) 
[19] Ulusoy, B.H., Çolakoğlu, N. (2018). What Do They Know About Food Safety? A Questionnaire Survey On Food Safety Knowledge of Kitchen Employees in İstanbul, Food and Health, 4(4): 283-292.

[20] Berber, M., Eser, B.Y. (2008). Türkiye'de Kadın İstihdamı: Ülke Ve Bölge Düzeyinde Sektörel Analiz, ISGUC The Journal of Industrial Relations and Human Resources, 10(2): 1-16.

[21] Özaydınlı, K. (2014). Toplumsal cinsiyet temelinde Türkiye'de kadın ve eğitim, Sosyal Politika Çalışmaları Dergisi, (33): 93-112.

[22] Çakıroğlu, F.P., Uçar, A. (2008). Employees Perception of Hygiene in The Catering Industry in Ankara (Turkey), Food Control, (19): 9-15.

[23] Bıyıkl1, A.E. (2011). Hastane Mutfaklarında Çalışan Aşçların Gıda Güvenliği Bilgi ve Uygulamalarının Belirlenmesi: Konya Il Merkezi Örneği, Yüksek Lisans Tezi, Selçuk Üniversitesi Sosyal Bilimleri Enstitüsü, Konya.

[24] Ulusoy, B.H., Çolakoğlu, N. (2018). What Do They Know About Food Safety? A Questionnaire Survey On Food Safety Knowledge of Kitchen Employees in İstanbul, Food and Health, 4(4): 283-292.

[25] Şanlıer, N., Hussein, A.T. (2008). Yiyecek- İçecek Hizmeti Veren Otel Mutfakları ve Personelinin Hijyen Yönünden Değerlendirilmesi: Ankara İli Örneği, Kastamonu Eğitim Dergisi, 6(2): 461-468.

[26] Şanlıer,, N., Türkmen, F. (2010). Perceptions of Hygiene among Staff Working in Food Companies, Research Journal of Medical Sciences, 4(3): 231-237.

[27] Eksen, M., Karadağ, N., Karakuş, A. (2004). Muğla merkez ilçe gıda işyerlerinde çalışanların el ve vücut hijyeni konusundaki bilgi düzeylerinin incelenmesi, $U G B D, 1(1): 1-21$.

[28] Özmen, S.A. (2009). İstanbul'daki bazı kasapların, şarküterilerin ve marketlerin et satışreyonlarının hijyen durumunun belirlenmesi, Yüksek Lisans Tezi, Namık Kemal Üniversitesi Fen Bilimleri Enstitüsü, Tekirdağ.

[29] Babür, T.E. (2007). Muğla'da ki birinci sinıf tatil köylerinde çalışan mutfak personelinin aldıkları hizmet içi eğitimi ve mutfak hijyen durumunun değerlendirilmesi, Yüksek Lisans Tezi, Selçuk Üniversitesi, Sosyal Bilimler Enstitüsü, Konya.

[30] Erçişli, S. (2005). Konya'da tüketime hazır yemek üreten ve bunları sunan işletmelerde çalışanların hijyen bilgisinin belirlenmesi, Yüksek Lisans Tezi, Selçuk Üniversitesi, Sosyal Bilimler Enstitüsü, Konya.

[31] Siau, A.M.F., Son, R., Mohhiddin, O., Toh, P.S., Chai, L.C. (2015). Food court hygiene assessment and food safety knowledge, attitudes and practices of food handlers in Putrajaya, International Food Research Journal, 22(5): 1843.

[32] Abdul-Mutalib, N.A., Abdul-Rashid, M.F., Mustafa, S., Amin-Nordin, S., Hamat, R.A., Osman, M. (2012). Knowledge, attitude and practices regarding food hygiene and sanitation of food handlers in Kuala Pilah, Malaysia, Food Control, 27(2): 289-293.

[33] Demirel, S. (2009). Hazır yemek üretimi yapan işletmelerde çallşanların hijyen bilgi düzeylerinin belirlenmesi, Yüksek Lisans Tezi, Namık Kemal Üniversitesi Fen Bilimleri Enstitüsü, Tekirdağ.

[34] Baş, M., Ersun, A.Ş., Kıvanç, G. (2006). The evaluation of food hygiene knowledge, attitudes, and practices of food handlers in food businesses in Turkey, Food Control, 17(4): 317-322.

[35] Anonim, 2013. Hijyen eğitimi yönetmeliği. Ankara: 5 Temmuz 2013 Tarih ve 28698 sayılı Resmi Gazete. 